\title{
Roses in Amber: Gendered Discourse in Disney's 2017 Adaptation of Villeneuve's Fairytale Beauty and the Beast
}

\author{
Atoof Abdullah Rashed \\ Department of European Languages \& Literature, Collage of Arts \& Humanities, \\ King Abdulaziz University, Jeddah, Saudi Arabia \\ Laila. M. Al-Sharqi \\ Department of European Languages \& Literature, Collage of Arts \& Humanities \\ King Abdulaziz University, Jeddah, Saudi Arabia \\ Corresponding Author: laila.alsharqi@gmail.com
}

Received: 10/28/2020 Accepted: $1 / 11 / 2021 \quad$ Published: $2 / 24 / 2021$

\begin{abstract}
This study considers the dialogic relationship between the 2017 Disney live-action film Beauty and the Beast with Gabrielle-Suzanne de Villeneuve's fairy tale and Disney's 1991 animated version. Drawing on cultural and feminist discourse, the study seeks to examine Disney's liveaction film for incidents of cultural appropriation of gender representation compared to Villeneuve's fairy tale and Disney's 1991 animated version. The Study argues that the 2017 film adaptation reverses the traditional patriarchal notions and embraces a transgressive feminist discourse/approach as part of Disney's strategy of diversity and inclusion of gender, race, class, and sexual orientation as constantly evolving cultural categories. This study finds significant alterations made to the physical and psychological attributes of the 2017 film's three characters: Beauty/Belle, the Beast, and the Enchantress, changes that align with the film's gendered discourse. By reversing the characteristic privileging of the male and the empowerment of the female, the live-action succeeds in addressing the contemporary audience demands of diversity and inclusion. The study concludes that the changes made in the 2017 film adaptation displace the oppressive patriarchal notions and stereotypical modes of representing the male and female as they have been perceived in the original fairy tale, for they are no longer compatible with contemporary cultures' assumptions on gender.

Keywords: adaptation, Beauty and the Beast, cultural studies, de Villeneuve, Disney, gendered discourse

Cite as: Rashed, A. A., \& Al-Sharqi, 1. M. (2021). Roses in Amber: Gendered Discourse in Disney's 2017 Adaptation of Villeneuve's Fairytale Beauty and the Beast. Arab World English Journal for Translation \& Literary Studies 5 (1) 126-143.

DOI: http://dx.doi.org/10.24093/awejtls/vol5no1.9
\end{abstract}




\section{Introduction}

Fairy tales are considered as influential sites for the construction of knowledge on gendered relations (Zipes, 2006, 2012). Having their origin in oral cultures, these fairy tales have been narrated repeatedly to young children in public and private spaces providing an essential source for the stereotypical images that perpetuate hierarchical gender forms of feminine and masculine behavior (Rice, 2000). While these fairy tales, such as Sleeping Beauty, Snow White, and Cinderella, which drew images of the female as obedient, submissive, and dependent, "continue to have a powerful effect" on how young and old [women] behave and relate to their daily activities (Zipes2006, 2012), many contemporary feminist writers and film producers have attempted to reverse these long-standing mental perceptions by presenting the female as strong, independent and resourceful. Donald Barthelme's Snow White (1967), for example, is a literary rewriting that attempted to redefine the stereotypical gendered notions portrayed in the original fairy tale by altering aspects related to male dominance. Andy Tennant's Ever After: A Cinderella Story (1998) is another film adaptation that reinvented the Cinderella character as a resourceful female whose liberation from a life of oppression did not merely consist in marrying a charming prince but in saving the life of her future husband.

Beauty and the Beast is one of the most famous fairy tales that have embedded gendered behavior and discourse, and which has been rewritten and adapted. Influenced by ancient Greek stories, the original printed version of this fairy tale appeared in 1740 in The Young American and Marine Tales, credited to Gabrielle-Suzanne Barbot de Villeneuve. In this novel, Beauty is presented as an obedient and self-sacrificing young woman. She is traded by her impoverished father for safety and material wealth and rewarded for her virtuous deeds of obeying her father and the Beast. Beauty is also rewarded for valuing his kindheartedness above physical good looks. (Bottigheimer, 1986). Extending beyond the literary domain, this tale, like many other fairy tales that emphasize patriarchal values (Foss, 1988), reinforces a cultural discourse that presents females as inferior beings (Zipes, 1989; 1995). As an archetypal story, Beauty and the Beast is a reflection of the dominant views about femininity during the $17^{\text {th }}$ and $18^{\text {th }}$ centuries. It emphasizes qualities of obedience, self-sacrifice, and fragility as highly desirable. As Lauran argues (2006), these qualities often become a kind of terrain where Beauty turns into a socio-cultural conceptualization of the approved qualities of femininity and womanhood. Young women with these qualities occupy good status in society as both loved and cherished. Other young women who do not possess or conform to these qualities can threaten social norms and conventions. Dominant views about femininity in Western culture have linked young women with these qualities as positive ideals, prerequisites in exacting femininity.

Although this fairy tale quickly became very popular and was adapted several times into many texts, plays, and film versions across Europe and the US, many of these adaptations continued to reinforce the patriarchal discourse found in the original work. Some examples include 
Pierre-Claude Nivelle de La Chaussee's play Amour pour amour (Love for love) (1742); La Belle et la Bête, a French classic romantic fantasy adapting the Beaumont version (Cocteau, 1946); and the (1991) Walt Disney amination Beauty and the Beast, based on Jeanne-Marie Le Prince de Beaumont version (1756) of the fairy tale. The latest 2017 Disney live-action version of the fairy tale, however, presented a counter-gender discourse that troubles female representation in the original novel. Many reviewers of the 2017 film adaptation, Beauty and the Beast, received it as an entertaining "face-lift" of the animated classic for its depiction of dazzling customs and stunning musical and visual treat to attract young and adult viewership alike (Gray, 2017; Rosenzweig, 2017). Other reviewers conceived in the film's treatment of gender a more significant contribution than mere entertainment. In an article review, Giese states that, unlike the 1991 animated Beauty and the Beast, which marked a renaissance for Disney in family entertainment, the 2017 Beauty and the Beast has not been the case. This is due to the latter's incorporation of "gay and transgendered elements," which Giese considers as inappropriate components for young viewers (2017, paragraph. 20). In another review, Gould argues that the film's significance lies not in its socio-political propaganda and presentation of "gender nonconformity" themes or "GLBT agenda" but in the work's ability to produce "higher and more immutable truth" (Gould, 2017, paragraph. 1).

Keeping abreast of the changing cultural ideologies in contemporary society, along with the various accompanying discourses and practices that have gained eminence since the 1900s (Zipes, 1995), this adaptation acknowledges spaces of difference in certain identity forms such as gender, race, and class. These cultural spaces stand as conjectures of the Disney company's evolving strategy of diversity, inclusion, and capacity for cultural introspection, enabling "subgroups" in the society to remain "relevant in a rapidly changing world" especially that "inclusion is a critical part of reflecting the diversity of [its] consumers" (Francoeur, 2004, pp. 12; "The Walt Disney Company diversity and inclusion commitment"). This strategy is evident in the several expansions, alterations, and additions made in the 2017 Beauty and the Beast to represent various marginalized groups reflecting aspects of gender, race, and class. One example is the inclusion of Lefou, a minor character created by Disney to be Gaston's underling, who, making an appearance in the 1991 Disney animation, who provides a direct representation of the queer sensibility with a sharply differing portrayal from his previous comedic appearance in the 1991 Disney animation (Attitude, 2017, paragraph 2). Another example of the racial inclusion strategy is Pere Robert, the black Chaplain who is the only person to be seen inside the church and who alone helps Belle after she is publicly abused by the rest of the village. Pere Robert shows his objections to the mob's enraged behavior against Belle and Maurice in a close-up shot that evinces his noninvolvement ${ }^{1}$ alongside the gay character, Lefou. Disney's incorporation of components related to gender discourse is by far the most critical contribution to this version. It is consistent with the increased interest in the construction of gender roles as social categories of analysis that inform notions of masculinity and femininity (Butler, 2007). It is thus essential to investigate the various additions and alterations made to the gendered components that Disney introduced to the 2017 Beauty and the Beast to enhance the feminist perspectives. The decision to study the various 
methods, narrative and otherwise, Disney employed in the 2017 film to problematize the original tale's representation of gender is vital. This study is also informed by the need to enrich the current scholarly interest in the intersection between literature and other mediums in connection to specific themes, such as gendered discourse, and theoretical approaches, such as intertextuality and adaptation studies, all of which have become part of the critics' fervent interest in the late twentieth century, in what Sanders identifies as the desire for finding connections between literary texts and other mediums and genres (Sanders, 2016). More specifically, this study will address the following research questions: What are the main alterations and additions Disney introduces in the 2017 Disney Beauty and the Beast in the representation of its depiction of the film protagonists; how do these alterations in character representation compare and contrast with the characters in the original tale; what impact do these alterations render on the reading/viewing experience of the film; and what are the possible meanings and implications of the film's revisionary impulse and the embedded reference to gender issues on various literary and cultural contexts. This study will thus provide a thorough understanding of the changing perspectives on gender to contribute to the current scholarly works studying film reworkings of classic fairy tales and exploring how these films diverge from sources to create their intertextual networks and connections. The findings of the study will also furnish grounds for future studies on gendered discourse in film adaptations.

\section{Literature Review Studies in film adaptations}

Many critics and scholars have speculated on the importance of cultural discourse in film adaptations. Corrigan (1998) and Niklas and Lindner (2012) argue that both film and literature can be discussed on common grounds provided by interdisciplinary and cultural studies. They give significant multidisciplinary perspectives on gender, race, class, and power. These aspects are culturally specific and evolve according to the shifting values of a given society. As Stam (2005) points out, they are "infinite and open-ended possibilities generated by all the discursive practices of culture" (p. 27), "encompassing different questions of power and difference" (Bracke, p. 46), which, according to Stam, motivate film adaptations. They indicate a reading process that measures not only "what is retained and how that is presented [but also] the extent and nature of inventions and departures from the original" (Dudley, 2000, p. 31). While the previous adaptation criticism, based on aspects of "fidelity," conceived of the inferiority of film to literature, cultural analysis of adaptations overcomes this prejudice by acknowledging their equal status, for, by their very nature, film adaptations are cultural constructs, "mosaics" shaped as much by intertextual and contextual forces as by their literary forbears; i.e., earlier works that "may have to alter the cultural, regional, or historical specifics of the text being adapted" (Stam, 2000, pp. 54-57) to cope with the continually evolving and changing cultural environments that Hutcheon defines as "palimpsest," "creative and interpretive transposition[s] of a recognizable other work or works ... a transcoding into different conventions" (Hutcheon, p. 33 2006). Similarly, Leitch, rejecting the limiting view of adaptation as fidelity to an original text, explores how the intertextual convergence of film adaptations as visual experiences and literature offers limitless discursive possibilities for understanding filmmakers' different approaches to adaptation (2007, p. 126). Jameson goes a step

Arab World English Journal for Translation \& Literary Studies 
further to state that film adaptations as products of cultural-historical processes that illustrate the changes in different notions, values, and social activities in contemporary culture tare "not only governed by a wholly different aesthetic," but "breathe an utterly different spirit altogether" (Jameson, 2011, p. 218). In the same vein, Andrew, categorizing film adaptations into three modes: borrowing, intersection, and fidelity, argues for the importance of the "sociological turn" and the "complex interchange between eras, styles, nations, and subjects" (Andrew, 2000, p. 37) that film adaptations produce concerning the adapted texts. Providing a historical overview of film adaptations since the turn of the twentieth century, Naremore capitalizes on the importance of giving more attention to the economic, cultural, and political issues these adaptations generate rather than the purely formal ones (Naremore, 2000, p. 8). To illustrate his view, Naremore quotes Fassbinder, who states that "cinematic transformation of a literary work should never assume that its purpose is simply the maximal realization of the images that the literature evokes in the minds of its readers" (qt in Naremore, 2000, p. 9).

\section{Studies on Disney's Beauty and the Beast}

The critical literature on Disney's 2017 Beauty and the Beast is scant. Only two studies are available on this work. The first study is by Koushik and Reed in which they argue that the film is a representative of a "corporate trend" that Disney adapts to commodify its film products by creating "feminists reimaginings of classic narratives" as part of its strategy to "maintain social and financial capital" (2018, p. 2). The second study is produced by Banerjee and Singh's who offer a queer reading of Emma Donoghue's The Tale of the Rose and Disney's 2017 Beauty and the Beast. The study examines these two works as appropriations of the heteronormative ideals of Madame Beaumont's Beauty and the Beast. The study argues that, although The Tale of the Rose and Disney's 2017 Beauty and the Beast present the lesbian relationship in the wake of the LGBTQ activism, they use subtle methods such as humor and veiled symbolism in their attempt to prioritize the mass reception of the film (2020). While the studies above discussed the 2017 Disney's Beauty and the Beast, none of these studies provided a full-length analysis of the gendered discourse relevant to the work. It is thus pertinent to fill the missing gap in the literature on the issue of gendered discourse.

\section{Methodology}

Drawing on cultural and feminist discourse, this study's objective is to explore the feminist aspects in Disney's 2017 film adaptation, Beauty and the Beast, as they are related to Villeneuve's 1740 work (with references to the 1991 animated version). Placing Disney's 2017 Beauty and the Beast at the center of a web of intertextual relations with these works, the study uses close reading and comparative analysis to examine how the 2017 Beauty and the Beast reverses a set of principles and characteristics around which the notion of gender is organized. Unlike Villeneuve's 1740 work, Disney's 2017 Beauty and the Beast, this study concludes, provides alternative qualities associated with the male-female relationship. This reversal is evident in the altered concepts of female submission and domesticity, the changing beauty standards, and the personality traits that Belle and the Beast exhibit to support in breaking the gender stereotyping cycle in ways

Arab World English Journal for Translation \& Literary Studies

ISSN: 2550-1542 | www.awej-tls.org 
that provide meaningful discursive practices recontextualized to resonate with the contemporary audience.

\section{Analysis and Results \\ The Empowered Beauty}

Consistent with its strategy of diversity and inclusion, Disney reimagines Belle in the 2017 live-action film to support feminism rather conspicuously. Although, as Gray states in HuffPost (2017), Belle displays certain feminist aspects in Villeneuve's original version, particularly her refusal to marry according to her father's desires, the emphasis is instead on physical beauty, charm, kindness, and selflessness as the most valued traits in women. To some degree, this is apparent in the animated classic; however, the 2017 version extends Belle's physical and psychological strength away from the previous gender stereotypes. As Gray claims, the 2017 film answers feminist objections to the "weak" Belle (who falls in love with her kidnapper) in the 1991 film by creating subplots and adding details that elucidate Belle's relationship with the Beast and amplify her independence, agency, and power.

The feminist aspects in the 2017 version are visible in Belle's character when comparing, for example, the clothing worn by the heroines in the different versions of the story. The fancy gowns Villeneuve's Beauty wears at the Beast's castle and the flowers she puts in her hair illustrate her soft and delicate character. In contrast, the 2017 Belle wears a farmer's outfit reminiscent of the attire she wears in the animation, but now she wears a toolbelt with her hem raised and folded on her right hip. This configuration reveals her bloomers and boots, which replace the ballet shoes chosen by the animators. Furthermore, when Belle is offered a wardrobe of fancy gowns, she uses the fabric to create an escape rope in a gesture that may represent a rejection of the conformity involved in donning typical gender-based clothing. Another example is when she disposes of her heels and the layers of her fancy gown on her way to rescue the Beast from the angry mob. Belle arrives at the battle between Gaston and the Beast in boots and underclothes, adjusting her clothes to make them shorter, lighter, more comfortable, and less restrictive to her movements. These changes in Belle's attire set her in contrast to Belle in the previous versions; they reflect her empowerment and her readiness to be involved and active.

The most apparent alterations of Belle's character extend to the qualities of her personality. In the original fairytale, Villeneuve presents Beauty as an example of "perseverance and firmness" as she can overcome hardship and adjust to the new conditions of her rural life (Villeneuve, 2014, p. 3). She forgets her past and focuses on revitalizing everyone around her: "there was nothing she did not do to amuse them" (p. 4). Her light spirit, wisdom, and high educational level help her endure her family's misfortunes with patience and joy. In her social relations, she is esteemed for her benign nature and always surrounded by admirers - except for her envious, scheming sisters, whom she also treats with benevolence and generosity.

Arab World English Journal for Translation \& Literary Studies 
In the 2017 version, Belle lacks Beauty's patience, contentedness, and cheerfulness as she is dissatisfied with her life in the village. Living in a primitive town as the only daughter of Maurice, a poor artist and music-box maker, Belle rejects her situation and longs for an escape from the "provincial life" (Condon, 2017, 0:017:19). She sings: "I want adventure in the great wide somewhere, I want it more than I can tell [...] I want so much more than they've got planned" (0:017:33). In the animated version, Belle is merely the daughter of an inventor but, in the 2017 film Belle is also an inventor. Her skills exceed even Maurice's; she invents the washing machine. The villagers view her as "odd," "strange," "funny," and "different from the rest of [them]," while she thinks of them as dull and simple (0:05:40-55, 0:07:30) Struggling to mingle with others, she suffers from public abuse when she attempts to teach a girl to read.

When the Beast imprisons her father, Beauty's response differs from Belle's. For instance, Beauty willingly sacrifices her freedom, believing that it was her request for the rose that caused her father's imprisonment. Resolved to hide her terror from her family, she pretends to be cheerful to ease their anxiety: "in their presence, she appeared to consider [the departure] as a happy event; it was only, however, to console her father and brothers, and not to alarm them more than necessary" (Villeneuve, 2014, p. 23). After she meets the Beast at the castle, Beauty fears his appearance and worries that he will eat her. Trembling with horror, she nevertheless continues to behave with the proper demeanor by "[saluting] him very respectfully," fulfilling her promise of surrender (p. 26). This response is similar to what occurs in the animation, in which Belle also fears the Beast's form but asks to be allowed to take her father's place in prison and accepts her fate as the Beast's eternal captive in the castle.

In the 2017 version, in contrast, Belle demonstrates heroic bravery when she meets the Beast. Holding a wooden stick, she speaks to him loudly and firmly; she even yells that he is a "liar" when he accuses Maurice of theft (Condon, 2017, 0:27:46). Belle asks the Beast to "[come] into the light" to reveal his form. This scene also occurs in the animation, but the Beast declines her request in this version (0:28:16). His refusal drives the intrepid 2017 Belle to approach him with a candelabra. When he denies her request to take her father's place, Belle locks herself inside the prison to force his hand. In contrast to her versions in the source text and the animation, Belle breaks her promise and plans to escape. Later, she argues with the Beast when he invites her to dinner: "You've taken me as your prisoner, and now you want to have dinner with me? [...] I'd starve before I ever eat with you" (0:42:48). While Villeneuve stresses Beauty's courteous manners, Disney's 2017 Belle is daring, courageous, and even willing to insult the intimidating Beast.

Another significant distinction is the contrast between Beauty's gratitude toward the Beast and Belle's general ingratitude. During her nightly conversations with the Beast, Beauty's attitude is obligatorily polite: "it was undoubtedly to him that she was indebted for the enjoyment of all imaginable amusements" (Villeneuve, 2014, p. 42). Even the animated Belle, in actions and words, expresses thankfulness to the Beast for his support and presents. The newest version of Belle, 
however, seldom shows the Beast any appreciation. She does not thank him after he helps her explore her past, apologizes for calling Maurice a thief, nor, most strikingly, attempts to protect her from wolves, during which he is injured. In the 1991 version, Belle, while tending to the Beast's wounds, ends their argument in a tender tone, saying, "By the way, thank you for saving my life." He replies, "You're welcome" as he leans toward her in a moment that reveals their growing tenderness toward each other (Trousdale, 1991, 0:47:45). In the 2017 version, however, Belle withdraws from the argument without expressing gratitude. Instead, she says, "Try to get some rest" (Condon, 2017, 1:01:04). Belle's lack of gratitude in this film version reflects her proud nature, as she refuses either to accept apologies or to appreciate favors.

An essential trait of the heroine - present in all three versions discussed here- is her fondness for books. While Villeneuve stresses Beauty's high level of education and her passion for reading in passing general remarks such as "her great taste for study could easily be satisfied in this place" (Villeneuve, 2014, p. 35), in the 2017 film Belle, the viewer finds concrete evidence of her vast knowledge of classic literature like Romeo and Juliet and William Sharp's poem Crystal Forest.

Compared with her depiction in the animated version, Belle shows physical strength and intelligence in the latest live-action film, particularly during the mob scene. In the 1991 version, after Belle returns to town, she struggles to protect Maurice from the angry crowd, while Gaston (the antagonist) not only belittles her but pulls her around with ease. This staging emphasizes her physical weakness as well as her inability to defend herself. After Gaston single-handedly throws Belle into a basement, she is rescued only with the assistance of an enchanted object. In the 2017 version, however, Belle is stronger and more courageous than her animated counterpart. She enters the town on horseback, dramatically blocking the mob's path. In her body language, facial expressions, and voice tone, she appears robust. She struggles against all attempts to confine her until she is finally dragged by two men and thrown into a carriage. She escapes by utilizing her mechanical knowledge as she aids her father with the proper tool to break the lock.

In terms of character development, Belle's strong will and independence in the 2017 liveaction version occur during the fight scene between Gaston and the Beast. Unlike her animated version, who plays a smaller role in this conflict, pleading verbally with Gaston to stop the violence, and pulls the Beast to safety; she is more physically involved. In the battle scene, she grabs Gaston's darts and breaks them across her knees, furiously yelling at him. She then proceeds to struggle with him over his gun. To save the Beast from Gaston, she runs across a falling bridge and jumps over a chasm. Eventually, she stands watching from a distance, as in the animation. Yet, Belle's physical dispute with Gaston and her active willingness to interfere in the fight reflects a shift from the animated heroine's passivity to a more robust live-action interpretation of her character.

Interestingly, Emma Watson who played Belle in the 2017 film after receiving support for her feminist activities, adds a strong appeal to the film's feminist approach. Watson has noted in 
Entertainment Weekly that she tried to "make [Belle] more proactive, and a bit less carried along with the story $[\ldots]$ and a bit more in charge of - and in control of - her own destiny." Having played the role of a powerful female in Harry Potter, Watson stands as a gender equality activist who gives young girls around the world characters to live up to, someone inspiring and strong (Collis, 2015). Watson's motivation for incorporating these alterations into the inner and outer dynamics of the role she plays stems from her desire to upgrade the animated character into a role model that could be idolized by young viewers: "Belle as a character represents a woman who is willing to stand outside of what is expected of her, and chase her dreams, chase her intuition, and I think that that will really resonate and really appeal" (Griffiths, 2016, paragraph. 3).

\section{The Weakened Beast}

To support its feminist agenda, and in contrast to his counterpart in the traditional fairy tale, the Beast's vicious actions and motives are sharply evident in Disney's live-action film. Weakened on several levels, a significant modification in the Beast's character is his life before transformed him into a beast. In Villeneuve's version, the Beast is perceived as a beloved and respected prince. He appreciates his Fairy Governess for her supervision: "[He] showed her the same deference, the same attention that [he] should have shown to [his] mother, and gratitude inspired [him] with as much affection for her" (Villeneuve, 2014, p. 88). He always respects the Fairy Governess's orders: "[she] permitted me [...] now she forbade me [...] I obeyed her without inquiring what were her reasons" (p. 88). He even remains polite under objectionable circumstances, as when he graciously refuses the Fairy Governess's marriage proposal rather than bluntly expressing his abhorrence:

Madame, I assure you (. . .) Although I am sincerely grateful to you for past favors, I cannot agree to discharge my debt to you by such means. . . Name any other mode of acknowledging your favors and I will not consider it impossible; but as to that you have proposed, excuse me if you please. (p. 93)

Villeneuve's Prince is a courteous character admired in his kingdom and even considered worthy of being a fairy's husband.

In the text, the Fairy Governess becomes infuriated after the Queen rejects her marriage proposal to the Prince and hints at her age, horror, and rank as the reasons she is unsuitable. Because the wicked Fairy believes that the Prince's excellence is a result of her work as a governess, she decides to deny him his virtues:

It is beauty, then, of this precious son of yours that renders you so vain $[\ldots]$ having taken so many pains to make him charming, it is fit that I should [...] give you both a cause $[\ldots]$ to make you remember what you owe to me. (p. 93)

Arab World English Journal for Translation \& Literary Studies 
After the Prince transforms into a beast, he is challenged to find a girl who is willing to marry him, but he must reveal neither his wit nor his royal status to help persuade her. If he cannot find anyone, he is doomed to remain a beast forever. The Prince does not deserve the Fairy's cruel punishment, since it was his mother who offended her in the first place.

Opposite to Villeneuve's blameless Prince, Disney, in both its versions, makes the Prince solely responsible for his damnation. In the opening scene of the 2017 film, the narrator describes a "selfish and unkind" prince who abuses his people while delighting in the countless luxuries of his castle (Condon, 2017, 0:00:50). He appears wearing a wig as a maiden applies his makeup, a scene that emphasizes his conceit, mostly concerning his appearance and interest in material possessions. He also demonstrates this trait by "[filling] his castle with the most beautiful objects and his parties with the most beautiful people" (0:00:56). During the ball scene at the beginning of the film, all the dancers before the Prince are women dressed in white, and he sits on his throne, observing them. The lyrics in the scene may also allude to his habit of choosing one of the dancers for his sexual pleasure at each ball: "See the maidens so anxious to shine; look for a sign that enhances chances; she'll be his special one" (0:01:31). In a brief montage, Disney provides an overwhelmingly negative portrayal of the Prince's careless lifestyle before he is cursed.

To set the curse in the live-action film, an old lady - the Enchantress in disguiseinterrupts the ball and requests shelter from the storm. The Prince laughs insolently and mocks her gift (a single rose), then orders her to leave. The old lady "[warns] him not to be deceived by appearances for beauty is found within" (Condon 2017, 0:02:32). The Enchantress, then, reveals her true identity and punishes the Prince by transforming him into a beast until he "could learn to love another and earn their love in return" (0:03:50). If he does fail before the last petal falls from the enchanted rose, he will remain a beast for eternity. While Villeneuve's Prince is guiltless, Disney curses the Prince by his folly to teach him a lesson about vanity.

After the metamorphosis, the Beasts of Villeneuve and Disney respond to their situations differently. In the text, the Prince's initial reaction is to feel anguish: "My despair rendered me motionless [...] our misery was too great to seek relief in [lamentations]... I [decided] to fling myself in the adjacent canal" (Villeneuve, 2014, pp. 94-95). After his suicide attempt, a good Fairy appears at the scene. She feels pity for him and decides to help him cope with his situation by adding magical luxuries to the castle so that, although he still feels lonely, he spends his time engaging in useful activities: "I read, I went to plays, I cultivated a garden which I had made to amuse me, and found something agreeable in everything I undertook" (p. 99). The Beast's emotional state is reflected in the castle's liveliness. Even though it is uninhabited, it contained a "gentle warmth" and did "not [have] the air of an old castle that had been deserted" (p. 10).

In the 2017 film, in contrast, the Beast's actions are more distinct. He lives in a state of despair and anger after he is cursed; his fear during the transformation causes him to tear up his portrait and lock himself in the castle. Inside the Beast's wing, another destroyed portrait hangs 
alongside a broken mirror and several shredded items. This image of broken objects alludes to the Beast's persistent anger. Although he has magic servants to keep him company and a magical book for entertainment, the Beast still dwells in desperation, gloominess, and fury, and his mood affects his surroundings. He acts out his frustration by breaking plates, roaring, and yelling at Belle and his servants.

Eventually, Belle has to scold him: "You should learn to control your temper" (Condon, 2017, 1:00:53). The Beast reflects on his emotions: "When I enter the room, laughter dies" (1:12:15). Contrary to Villeneuve's Prince's effects on his surroundings, the disturbed emotions of Disney's Beast are mirrored in his castle. Although many people inhabit it, the castle remains bleak, disorganized, dusty, and seemingly empty. Only when Belle and the Beast become friends that the servants finally clean the rooms and open the curtains to let in the sunlight.

Another significant difference between the original text and the 2017 film is the Beast's treatment of Beauty/Belle and her father during their initial interactions. In the text, the Beast is generous and hospitable toward his guests. Arranging a proper feast, accommodation, and multiple chests for his guests to fill with all the riches they desire, the Beast asks them to "choose anything which both of [them] think will give pleasure to [her] brothers and sisters" (Villeneuve, 2014, p. 27). Even though he threatens death to the merchant for plucking a rose, the Beast later explains that he was only following the good Fairy's plan to help him break the spell: "threaten him that death will be the punishment of his audacity, unless he give[s] you one of his daughters" (p. 100).

In the live-action film, however, the Beast behaves ruthlessly and viciously towards both Belle and Maurice when he first encounters them. He attacks Maurice for plucking a rose and imprisons him inside of his tower. At the end of the scene, the Beast drags the defenseless Maurice across the stairs as he throws him out of the castle. After Belle takes her father's place, the Beast callously mocks her sacrifice: "You took his place? [...] He's a fool, and so are you" (Condon, 2017, 0:29:55).

The Beast's treatment of Beauty/Belle during her stay in his castle reveals even more of his personality. Villeneuve's Beast, for example, abstains from connecting with Beauty for fear that "[his] heart might betray its tenderness" and force him to reveal his identity (Villeneuve, 2014, p. 101). He allows Beauty to entertain herself in the castle without restrictions and says, "Wish for whatever you please, you shall have it" (p. 43). He treats her with "gentleness," enquires about her daily habits, "[pays] her compliments" (pp. 44-5), expresses empathy, and respects her needs. He even shortens his visit after noticing her discomfort; "The Beast observed her impatience, and came merely to say goodnight, that she might have more time to sleep" (p. 47). It is his good conduct that eventually transforms Beauty's fear into tenderness: 
The weariness she had felt at first in listening to the Beast had entirely departed [...] she had become more familiar with the Beast, either from the habit of seeing him or from the gentleness which she had discovered in his nature. (pp. 47-8)

Even the father, who hated him at first, considers him to be a suitable husband for Beauty, given his manners:

Discovering in this Beast too noble a mind to be lodged in so hideous a body, he deemed it his duty to advise his daughter to marry him, notwithstanding his ugliness [...] observing so much civility in the Beast, he could not believe him to be as stupid as she represented him. (Villeneuve, 2014, pp. 58-9)

Although he rarely communicates with them, the Beast wins their favor through his generosity and kindness.

In both of Disney's versions, the Beast displays behavior quite unlike that of the Beast in Villeneuve's text. The animated Beast shows some compassion on the first night of Belle's stay as he rubs his neck to relieve the stress and shame that he feels at having made Belle cry. Following the advice of his enchanted servants, he provides Belle with a good bedroom, invites her to dinner, and assures her that his castle and servants are at her command: "The castle is your home now so you can go anywhere you like [...] Now if you need anything, my servants will attend you" (Trousdale, 1991, 0:24:43). In an act of politeness and friendship, he expresses sympathy for Belle by following his servants' guidance. In contrast, the 2017 Beast is abrasive and indifferent, much more often than the 1991 character. He leaves Belle locked in the tower, denies her dinner, and furiously objects when the servants try to help her: "You're making her dinner? [...] You gave her a bedroom?" (Condon, 2017, 0:41:18). Even when the servants suggest using her to break the spell, the Beast replies with disgust, "She's the daughter of a common thief. What kind of person do you think that makes her?" (0:41:50). Continuing to show little interest in her troubles, however, he eventually complies with the servants' advice and improves his treatment of Belle.

Another clear distinction between Disney's two versions of the Beast concerns how the characters introduce their library. In the 1991 version, after the Beast begins to develop feelings for Belle, he decides that he "want[s] to do something for her" (Trousdale, 1991, 0:50:00). Since she loves reading, the Beast shows her to his massive library and joyfully tells her, "It's yours" $(0: 51: 10)$. This gesture stems from the Beast's desire to please Belle, which reflects his kindhearted nature. In the 2017 film, however, the Beast introduces Belle to the library after he ridicules her literary preferences by showing off his collections' greater worth. The Beast fails to recognize Belle's amazement until she expresses her joy; he then replies, "If you like it so much, then it's yours" (Condon, 2017, 1:06:43). In contrast to the romantic appeal shown in the two characters' kind gestures in the 1991 version, the live-action film dismisses any act of intimacy between the characters by demonstrating the Beast's indifference to Belle's intelligence.

Arab World English Journal for Translation \& Literary Studies 
The Beast's disturbed personality in the 2017 film is given some context through a scene from his childhood that reveals his father's emotional damage inflicted on him. As a character explains: "The master lost his mother and his cruel father took that sweet innocent lad and twisted him up to be just like him" (Condon, 2017, 1:01:23). This passing reference to the Beast's painful childhood, which includes no further details regarding the father's motives or the Prince's gradual change, seems to have been added arbitrarily to justify the Beast's character flaws. Dan Stevens, the actor who plays the Beast, describes his character's unsettled personality in an interview with The Hollywood Reporter: "The beast has driven Belle away and now that he can't love her, who could he ever love?" (Lee, 2017, paragraph. 6).

To enhance the beast's altered character traits, this live-action version adds a new song, Evermore, in addition to two other songs, Days in the Sun and How Does a Moment Last Forever, to provide the Beast an opportunity to express his love for Belle as she leaves the castle and returns to her village, whereas the animated Beast shows his sorrow only through body language without directly communicating his feelings to the audience.

Why, then, did Disney change the Beast from the tender personality found in the text and the animation into a cold-hearted, impertinent character? One answer might be that the producers of the 2017 version thought that a feminist approach entailed focusing on the Beast's weaknesses to intensify the strength of Belle's character. When juxtaposed against such a fierce obstacle, Belle appears even more powerful and effective than in the animated version in influencing the stubborn Beast's faults. Ultimately, this strategy highlights Belle's strengths and promotes her as an independent, feminist heroine.

\section{The New Enchantress}

Another character change in the 2017 version that promotes a sense of feminism is evident when comparing the Fairy Governess in Villeneuve's tale with Disney's live-action Enchantress. In the text, the Prince's Fairy Governess is "vindictive" and someone whom "people feared more than they loved" (Villeneuve, 2014, p. 86). She is mean-spirited not only inwardly but also outwardly, and she is "old," "naturally hideous," and "horribly ugly" (pp. 89, 91). She imprisons innocent fairies, manipulates a king to marry her, plans to murder Beauty as an infant, and unjustifiably transforms the Prince into a beast. By the end, she is imprisoned for her evil deeds, and the good Fairy says, "Yes, Prince, [...] you have no longer anything to fear from your enemy. She is stripped of her power and will never again be able to injure you by other spells" (p. 132). This ending is a fitting punishment for the Fairy Governess's cruel deeds.

Disney's Enchantresses play different roles in their respective films. The animated Enchantress appears only in the opening scene to curse the Prince. Although she aims to teach the Beast a lesson, her absence makes her seem unjust for cursing him and renders her lesson more elusive. In the live-action film, however, the beautiful Enchantress remains involved throughout the film to help the Prince learn from his mistakes. After transforming him, she gifts him a magical

Arab World English Journal for Translation \& Literary Studies 138

ISSN: 2550-1542 | www.awej-tls.org 
book that enables him to travel around the world. This gesture is added to the story to demonstrate her kind intentions. She lives inconspicuously in Belle's town as the poor widow, Agatha, to help break the spell. For example, she causes a lightning-struck tree to fall onto Maurice's path, which forces him in the castle's direction. The Enchantress also rescues Maurice from Gaston's deathtrap in the woods. She, then, goes to the castle with the rest of the villagers to witness Belle's confession of love and lift the curse.

Although the Enchantress hardly utters a word, her presence throughout the story heightens her benevolence. It serves to support her decision to discipline the Beast to impart a more profound lesson than is possible in the animated version. Gould (2017) observes that the film turns the Enchantress into a saint by making her punishment merciful as it protects the Beast from his flaws. The Enchantress was altered for the 2017 film to support the feminist messaging, changing her wicked nature to be motivated by compassion instead of hostility. ${ }^{2}$

\section{Discussion}

In its live-action production, Beauty and the Beast (2017), Disney addressed the subject of reversed patriarchy in the characters of Beauty/Belle, the Beast, and the Enchantress by exploiting the loose nature of adaptations. Redefining Villeneuve's classic fairy tale in matters of gender roles served the Disney company's approach to celebrate diversity and inclusion. Like other previous film adaptations, including Donald Barthelme's Snow White (1967) and Andy Tennant's Ever After: A Cinderella Story (1998), the female gains power in both appearance and character in opposition to her original weakness and submissiveness found in the text. Altering the stereotypical female roles in fairy tales (Foss, 1988), Disney and other filmmakers addressed the contemporary audience demands for diversity and equality, among other aspects (Ahmed, 2012; Bracke 2014,). Establishing a fearless Belle in place of her past versions that adhere to stereotypical femininity, drawing the Beast's character close to beastliness, and shifting the Enchantress's past wickedness to compassion reflects the issues Disney addresses to respond to their viewers' voices. Making use of adaptations' flexible forms, Disney managed to not only adapt Villeneuve's text but also to directly borrow from its animated version to incorporate diversity and inclusion within its productions.

\section{Conclusion}

This study examined the 2017 Disney film adaptation, Beauty and the Beast, as one of the significant adaptations of Gabrielle-Suzanne de Villeneuve's classic fairy tale. The study's objective is to gain a more profound insight into the different strategies, narrative and otherwise, Disney employed in its construction to problematize the original tale's representation of gender. This study is also informed by the need to reassess the long-standing hegemonic and patriarchal forms of gender domination by examining the implications of the intertextual relation between Villeneuve's classic fairy tale and Disney's aminated and live-action versions to demonstrate how the intersection between literature and film are used as significant sites of discourse through which cultural transformation and appropriation can be explained. Disney's 2017 version of Beauty and 
the Beast provides a significant example of cultural appropriation in its alteration of Villeneuve's 1740 novella of the fairy tale (with references to the 1991 animated version). The alterations occur in the depiction of several characters, all made to support aspects of gender negotiation. Although Disney's 2017 version of Beauty and the Beast may seem to depend on the guaranteed loyalty of the audiences to the original fairy tale, a closer examination of the film, the study argues, essentializes the male-female relationship consistent with Disney's strategy of diversity and inclusion. This is demonstrated in the variations the protagonist and other major characters revealed. The protagonist, Belle, is reimagined in the film to support feminism by the changes shown not only in her strengthened physical attire and rejection of typical gender-based clothing but also in her empowered character. In the 2017 version, in contrast to the original tale, Belle demonstrates stalwart bravery and pride in her encounters with the Beast. Furthermore, Disney makes the Prince solely responsible for his damnation, and, in his transformed persona to the Beast, he is shown as weakened, despaired, and angered. In the text, the Beast is generous and hospitable toward his guests. In the live-action film, however, the Beast behaves ruthlessly and viciously towards both Belle and other characters like Maurice. These alterations, the study revealed, significantly contribute to the ongoing debates on diversity and inclusion as fundamental principles of recognition crafting the present and future of contemporary cultures.

\section{Endnotes}

1. It should be noted, though, that neither ethnicity nor homosexuality plays a significant role in the development of the plot; these elements seem to have been added without details or context to support their inclusion. Fatima al-Sayed calls this "depthlessness," a tactic related to the approach to diversity and inclusion Disney has applied to Beauty and the Beast. She defines this tactic as a mere "insertion" of the characters into existing narratives with little effort to modify the plot or amplify the minorities' voices: "The narrative of the film itself hasn't actually changed in any way, Disney has just inserted diversity $[\ldots]$ those same people aren't controlling the narrative - the voice they've been given isn't their own" (Al-Sayed, 2019, paragraph. 9).

2. This is not the first time that Disney has converted a corrupt female into a favorable character. For example, Maleficent (2014) is a metafictional remake of Disney's The Sleeping Beauty (1959) and another adaptation, primarily based on the fairy tales of Charles Perrault (1696) and the Grimm brothers. This version reshapes the fairy tale by making the wicked witch, Maleficent, the protagonist. It presents her as a "benevolent character" who looks after the cursed princess and searches for a way to lift her curse (Khan, 2017, pp. 22-23). Changing the roles of "evil females" in fairy tales to justify their curses or add complexity to their characters maybe Disney's method of adopting, or at least of appearing to adopt a feminist approach to film as part of their diversity and inclusion strategy.

Arab World English Journal for Translation \& Literary Studies 


\begin{abstract}
About the Authors
Atoof Abdullah Rashed received her MA degree in English from the Department of European Languages and Literature at King Abdulaziz University, Saudi Arabia in 2020. She wrote a number of short stories and adaptation scripts of original plays. Her research interests are in the area of postmodern literature and adaptation theory. ORCID ID. https://orcid.org/0000-0003-0381-6366
\end{abstract}

Laila Mohammed Al-Sharqi is an associate professor of English in the Department of European Languages and Literature at King Abdulaziz University, Saudi Arabia. She received her Ph.D. in Cultural Studies from the University of Nottingham. Her research interests include postmodern literature, literary theory, gender studies. "Magical realism as a feminist discourse in Raja Alem's Fatma" and "Twitter Fiction: A new creative literary landscape" are examples of her research. ORCID ID. https://orcid.org/0000-0001-8142-1525

\title{
References
}

Al-Sayed, F. (2019). Beauty and the Beast: The controversies. The Blank Page, Available at http://home.blnkpage.org/artslife/beauty-beast-controversies/.

Andrew, D. (1984). Concepts in film theory. Oxford: Oxford University Press.

Andrew, D. (2000). Adaptation. In J. Naremore (Ed.), Film adaptation (pp. 28-37). New Brunswick, New Jersey: Rutgers University Press.

Attitude. (2017, March 1). World exclusive: Beauty and the beast set to make Disney history with a gay character. Available at https://attitude.co.uk/article/world-exclusive-beautyand-the-beast-set-to-make-disney-history-with-gay-character-1/13725/.

BBC News. (2020, March 13). Disney promises LGBT 'commitment': 'We want to represent our audience.' Available at https://www.bbc.com/news/newsbeat-51871026.

Barthelme, D. (1996). Snow White. New York: Simon and Schuster.

Banerjee, P., \& Singh, R. (Dec 2020). Revisioning Madame Beaumont's 'Beauty and the Beast' in Emma Donoghue's the tale of the rose' and the 2017 Disney version: A queer reading. Journal of Language, Literature, and Culture. https://doi.org/10.1080/20512856.2020.1851161

Bottigheimer, R. B. (1986). Fairy tales and society: Illusion, allusion, and paradigm. Philadelphia: University of Pennsylvania Press.

Bracke, S. (2014). The unbearable lightness of "gender and diversity." Journal of Diversity and Gender Studies, 1(1), 41-50.

Butler, J. (2007). Gender trouble: Feminism and the subversion of identity. New York: Routledge.

Cobb, Shelly. (2010). Adaptation, fidelity, and gendered discourse. Adaptation, 4(1), 28 -37.

Cocteau, J. (Director). (1947). La belle et la bête [Film]. DisCina.

Collins, J. (2010). Bring on the books for everyone: How literary cultures became popular cultures. Durham \& London: Duke University Press. 
Collis, C. (2015, November 4). Beauty and the Beast: Emma Watson on playing a more "proactive" Belle. Entertainment Weekly. Available at https://ew.com/article/2016/11/04/beauty-and-beast-emma-watson-belle/.

Condon, B. (Director). (2017). Beauty and the beast [Film]. Walt Disney Pictures.

Corrigan, T. (1998). Film and literature: An introduction and reader. Upper Saddle River, New Jersey: Prentice-Hall.

Eberts, J. F. (2012). Adaptation: Is the book really better than the...television series? (Unpublished Senior Thesis). Scripps College. Claremont, California.

Foss, S. K. (1988). Judy Chicago's "The dinner party": Empowering of women's voice in visual art. In B. Bates and \& A. Taylor, (Eds.), Women communicating: Studies of women's talk (pp. 9-26). Norwood, New Jersey: Ablex.

Francoeur, B. (2004). Brand image and Walt Disney: A qualitative analysis of magical gatherings. University of Wisconsin-La Crosse Journal of Undergraduate Research, 7, $1-8$.

Giese, T. (2017, March 23). Movie review: Beauty and the beast. Available at https://blogs.lcms.org/2017/beauty-and-the-beast.

Gould, A. (2017, March 28). Finding beauty in Beauty and the beast-The perspective of an Orthodox Christian artist. Orthodox Arts Journal. Available at https://orthodoxartsjournal.org/finding-beauty-beauty-beast-perspective-orthodoxchristian-artist/.

Gray, E. (2017, March 20). How Disney subtly made Beauty and the beast more feminist. HuffPost. Available at https://www.huffpost.com/entry/how-disney-subtly-made-beautyand-the-beast-more-feminist_n_58cfd97ce4b0ec9d29dd676f.

Griffith, E. (2016, December 31). Hear Emma Watson sing in Beauty and the Beast for the first time. Hello. Available at https://www.hellomagazine.com/film/2016123135500/hearemma-watson-sing-for-the-first-time-in-beauty-and-the-beast/.

Hutcheon, L. (2006). A theory of adaptation. Routledge.

Jameson, F. (2011). "Adaptation as a philosophical problem". True to the spirit: Film adaptation and the question of fidelity. Ed MacCabe, C. \& Murray, K. \& Warner, R. (pp. 215-233). Oxford: Oxford University Press.

Khan, M. A. (2017). Maleficent: Reimagining 'the sleeping beauty' with a post-modernist perspective. International E-Journal of Advances in Social Sciences, 3(8), 616-624.

Koushik, K., \& Reed, A. (2018). Star Wars: The last Jedi, Beauty and the Beast, and Disney's commodification of feminism: A political-economic analysis. Social Sciences, 7(11), 121.

Laurance, A. (2006). Women, godliness, and personal appearance. Women's History Review, $15(1), 69-81$.

Lee, A. (2017, March 14). Beauty and the Beast composer Alan Menken on rediscovering lost lyrics and why he's "shutting up" about that gay character. The Hollywood Reporter. Available at https://hollywoodreporter.com/heat-vision/beauty-beast-new-songscomposer-alan-menken-lost-lyrics-gay-character-985602.

Arab World English Journal for Translation \& Literary Studies

ISSN: 2550-1542 | www.awej-tls.org 
Leitch, T. (2007). Film adaptation and its discontents: From Gone with the wind to the passion of the Christ. Baltimore, MD: Johns Hopkins University Press.

Naremore, J. (2000). "Film and the region of adaptation". Film adaptation. New Brunswick, NJ: Rutgers University Press.

Nicklas, P., \& Linder, O. (Eds.). (2012). Adaptation and cultural appropriation: Literature, film, and the arts. Berlin: De Gruyter.

Rice, P. S. (2000). Gendered readings of a traditional "feminist" folktale by sixth-grade boys and girls. Journal of Literacy Research, 32(2), 211-236. https://doi.org/10.1080/10862960009548074

Rosenzweig, A. (2017, March 22). Movie review: Beauty and the beast charms audiences. PennState Commedia. Available at https://www.commmedia.psu.edu/commradio/story/movie-review-beauty-and-the-beastcharms-audiences.

Sanders, J. (2016). Adaptation and appropriation. London: Routledge.

Stam, R. (2000). Beyond fidelity: The dialogics of adaptation. In J. Naremore- (Ed.), Film adaptations (pp. 54-67). New Brunswick: Rutgers.

Stam, R. (2005). Introduction: The theory and practice of adaptation. In R. Stam, \& A. Raengo (Eds.), Literature and film: A guide to the theory and practice of film adaptation (pp. 152). Malden, MA: Blackwell.

Tennant, A. (Director). (1998). Ever After: A Cinderella story [Film]. Fox Family Films.

Trousdale, G. (Director). (1991). Beauty and the beast [Film]. Walt Disney Pictures.

Villeneuve, G.-S. B. de. (2014). Madame de Villeneuve's the story of the beauty and the beast (J. R. Planché, Trans., R. L. Lawrence, Ed.). Ilminster, Somerset: Blackdown Publications.

The Walt Disney Company. (2014, December 16). The Walt Disney Company recognized for diversity leadership. Available at https://thewaltdisneycompany.com/the-walt-disneycompany-recognized-for-diversity-leadership/.

The Walt Disney Company. (2018, April). The Walt Disney Company diversity and inclusion commitment. Available at https://thewaltdisneycompany.com/app/uploads/2019/09/DiversityAndInclusionCommit ment.pdf.

Zipes, J. (1989). Beauties, beasts, and enchantment: Classic French fairy tales. New York: New American Library.

Zipes, J. (1995). "Breaking the Disney spell” from mouse to mermaid: The politics of film, gender, and culture. Bloomington: Indiana University Press.

Zipes, J. (2006, 2012). Fairy tales and the art of subversion. The classical genre for children and the process of civilization. New York: Routledge.

Arab World English Journal for Translation \& Literary Studies 